J. Clin. Chem. Clin. Biochem.

Vol. 20, 1982, pp. 473-476

\title{
Increased Urinary Excretion of Angiotensin Converting Enzyme in Patients with Renal Diseases
}

\author{
By I. Kato, Y. Takada, K. Nishimura, K. Hiwada and T. Kokubu \\ The 2nd Department of Internal Medicine, Ehime University School of Medicine, \\ Shigenobu, Onsen-gun, Ehime 791-02, Japan
}

(Received November 11, 1981/February 23, 1982)

Summary: We measured the activity of angiotensin converting enzyme (EC 3.4.15.1) in urine samples from normal subjects and patients with nephrotic syndrome and chronic glomerulonephritis. Urinary excretion of angiotensin converting enzyme in patients with nephrotic syndrome $(1.58 \pm 0.50$ (SD) units/day; $n=15)$ and chronic glomerulonephritis $(1.01 \pm 0.45$ units/day; $n=12)$ was significantly increased compared with normal subjects $(0.38 \pm 0.10$ units/day; $n=18$ ). It was demonstrated that a high molecular weight form of the enzyme (more than 400000 ) was mainly excreted in urines from patients with nephrotic syndrome. After trypsin treatment, this form was altered to a low molecular weight form (290000). These two different forms of urinary angiotensin converting enzyme were compared with the enzyme purified from human kidney, and found to be identical with respect to $K_{\mathrm{m}}$ value ( $2 \mathrm{mmol} / \mathrm{l}), \mathrm{pH}$ optimum ( $\mathrm{pH} 8.3)$, chloride ion dependency $(0.8 \mathrm{~mol} / \mathrm{l})$, inhibitory effect of captopril $\left(\mathrm{I}_{50}\right.$, $21 \mathrm{nmol} / \mathrm{l}$ ), and behaviour towards antiserum to human kidney angiotensin converting enzyme.

\section{Erhöhte Ausscheidung von Angiotensin Converting Enzyme im Harn bei Patienten mit Nierenerkrankungen}

Zusammenfassung: Bei Patienten mit nephrotischem Syndrom und chronischer Glomerulonephritis sowie bei Gesunden wurde Angiotensin Converting Enzyme (EC 3.4.15.1) im Harn bestimmt. Die Ausscheidung des Enzyms $(\overline{\mathrm{x}} \pm \mathrm{s})$ war bei nephrotischem Syndrom $(1,58 \pm 0,50 \mathrm{U} / \mathrm{d} ; \mathrm{n}=15)$ und Glomerulonephritis $(1,01 \pm 0,45 \mathrm{U} / \mathrm{d}$; $\mathrm{n}=12) \mathrm{im}$ Vergleich zu Gesunden $(0,38 \pm 0,10 \mathrm{U} / \mathrm{d} ; \mathrm{n}=18)$ signifikant erhöht. Im Harn von Patienten mit nephrotischem Syndrom wurde hauptsächlich die Form des Enzyms mit hohem Molekulargewicht $\left(M_{\mathrm{r}}>400000\right)$ ausgeschieden. Einwirkung von Trypsin veränderte das Enzym zu einer Form mit geringem Molekulargewicht $\left(M_{\mathrm{r}}=290000\right)$. Beide Formen wurden mit dem aus menschlichen Nieren gereinigten Enzym verglichen. Sie waren hinsichtlich $K_{\mathrm{m}}$-Wert (2 mmol/1), pH-Optimum (pH 8,3), Chlorid-Abhängigkeit $(0,8 \mathrm{~mol} / \mathrm{l})$, Hemmwirkung von Captopril $\left(I_{50}=21 \mathrm{nmol} / 1\right)$ und Verhalten gegen Antiserum gegen das Ëzym aus Niere identisch.

\section{Introduction}

Angiotensin converting enzyme (EC 3.4.15.1) converts angiotensin I to angiotensin II by releasing the C-terminal dipeptide (1). It also inactivates bradykinin and is identical with kininase II $(2,3)$. Ward et al. (4) and Caldwell et al. (5) have reported that the brush border membrane of renal proximal tubules contains a high concentration of angiotensin converting enzyme. We have reported that angiotensin converting enzyme is excreted in normal human urine and that urinary excretion of the enzyme is related to sodium excretion (6).

In this study, we measured the activity of urinary angiotensin converting enzyme in patients with nephrotic syndrome and chronic glomerulonephritis and found that they excreted significantly higher angiotensin. converting enzyme than normal subjects. The character of the enzyme excreted in urine under pathological conditions was studied.

\section{Materials and Methods}

\author{
Materials \\ Hippuryl- $L$-histidyl- $L$-leucine (hippuryl-His-Leu) was purchased \\ from Protein Research Foundation, Minoh, Osaka, Japan. The \\ molecular weight marker kit was from Boehringer Mannheim \\ GmbH, West Germany. Sephadex G-200 was from Pharmacia \\ Fine Chemicals AB, Uppsala, Sweden. Trypsin (11000 N- $\alpha$ - \\ benzoyl-L-arginine ethyl ester (BAEE) units/mg protein) was \\ from Sigma Chemical Co., St. Louis, MO., U.S.A. Captopril \\ (INN) was kindly supplied from Sankyo Co., Ltd., Tokyo, Ja- \\ pan.
}

\section{Probands}

Normal subjects and patients with renal diseases: 18 normal subjects (male, $n=10$; female, $n=8$; mean age, $45 \pm 16 a(S D)$ ) were medical staffs and volunteers. Sodium was not restricted. Patients with nephrotic syndrome and chronic glomeruloncphritis admitted in our clinic were placed on a diet containing $5.8-7 \mathrm{~g}$ sodium chloride per day and received no drugs during the examination.

15 nephrotic patients (male, $\mathrm{n}=10$; female, $\mathrm{n}=5$; mean age, $36 \pm 19 a$ ) were diagnosed according to the following criteria; 
more than $3.5 \mathrm{~g}$ of daily proteinuria, hypoalbuminaemia (less than $3 \mathrm{~g} / \mathrm{dl}$ ), hyperlipidacmia (total cholesterol, more than $350 \mathrm{mg} / \mathrm{dl}$ ) and oedema. The mean urea nitrogen and creatinine concentrations in serum were $19.6 \pm 9.8$ (SD) $\mathrm{mg} / \mathrm{dl}(12-44 \mathrm{mg} /$ $\mathrm{dl})$ and $1.37 \pm 0.90 \mathrm{mg} / \mathrm{dl}(0.7-4.4 \mathrm{mg} / \mathrm{dl})$, respectively. In 15 nephrotic patients, 7 patients had a renal biopsy which revealed histopathological features (minimal change, $n=3$; membranous nephropathy, $\mathrm{n}=3$; membranoproliferative glomerulonephritis, $\mathrm{n}=1)$.

12 patients with chronic glomerulonephritis (male, $n=6$; female, $n=6$; mean age, $35 \pm 14 a$ ) were diagnosed according to the following criteria; persistent proteinuria (more than 1 year), casts, especially erythrocyte casts, microscopic haematuria, exclusion of collagen diseases, diabetic and gouty nephropathy, essential hypertension, pyelonephritis, orthostatic proteinuria and toxic nephropathy. The mean serum urea nitrogen and creatinine concentrations were $27.9 \pm 22.3 \mathrm{mg} / \mathrm{dl}(12-75 \mathrm{mg} / \mathrm{dl})$ and $2.38 \pm 2,18 \mathrm{mg} / \mathrm{dl}(0.7-6.2 \mathrm{mg} / \mathrm{dl})$, respectively. 5 of 12 patients had a renal biopsy which confirmed the histological diagnosis (membranous nephropathy, $n=4$; membranoproliferative glomerulonephritis, $n=1$ ).

\section{Urine samples}

$24 \mathrm{~h}$ urines were collected at $4{ }^{\circ} \mathrm{C}$. Urine samples $(50 \mathrm{ml})$ were adjusted to $\mathrm{pH} 7.0$ with $1 \mathrm{~mol} / 1 \mathrm{NaOH}$. The sample was centrifuged at $3000 \mathrm{~min}^{-1}$, for $20 \mathrm{~min}$ at $4^{\circ} \mathrm{C}$. The supernatant was fractionated with $3.14 \mathrm{~mol} / \mathrm{l}$ ammonium sulfate. The precipitate was dissolved in $8 \mathrm{ml}$ and dialysed against $10 \mathrm{mmol} / \mathrm{l}$ phosphate buffer, $\mathrm{pH}$ 7.8. The approximately 5 -fold concentrated sample was again centrifuged at $8000 \mathrm{~min}^{-1}$ at $4{ }^{\circ} \mathrm{C}$ and the supernatant was used for the determination of the enzymic activity. During the preparation of the enzyme material, the recovery of enzymic activity was approximately $70 \%$.

\section{Assay of angiotensin converting enzyme activity}

Angiotensin converting enzyme activity was measured by the modified method of Cushman \& Cheung (7). The total $1 \mathrm{ml}$ assay mixture contained $80 \mathrm{mmol} / \mathrm{l}$ borate-sodium carbonate buffer, $\mathrm{pH} 7.8,2 \mathrm{mmol} / 1$ hippuryl-His-Leu and $0.2 \mathrm{ml}$ concentrated urine sample. The assay mixture was incubated at $37^{\circ} \mathrm{C}$ for $120 \mathrm{~min}$ and the reaction was stopped by adding $0.5 \mathrm{ml}$ of $1 \mathrm{~mol} / 1 \mathrm{HCl}$. The hippuric acid was extracted with $3 \mathrm{ml}$ of ethyl acetate by vortex mixing for $20 \mathrm{~s}$. Two $\mathrm{ml}$ of the extract was evaporated and dried, and then $2 \mathrm{ml}$ of distilled water was added. The concentration of hippuric acid was determined by measuring the absorbance at $228 \mathrm{~nm}$ against a zero time blank prepared by adding $0.5 \mathrm{ml}$ of $1 \mathrm{~mol} / 1 \mathrm{HCl}$ to the assay mixture before the reaction. One unit of the enzymic activity was defined as that amount of the enzyme which hydrolysed $1 \mu \mathrm{mol} / \mathrm{min}$ of hippuryl-His-Leu at $37^{\circ} \mathrm{C}$ under the described condition.

\section{Gel filtration}

Gel filtration of a column of Sephadex G-200 $(2.6 \times 90 \mathrm{~cm})$ for the determination of the apparent molecular weight was carried out by the method described previously (8).

\section{Other procedures}

The concentration of sodium in the urine sample was measured by a flame photometer (Beckman, Klina Flame). Protein was measured by the method of Lowry et al. (9). Anti-human kidney angiotensin converting enzyme antiserum used in this study was described previously (10). $5 \mu \mathrm{l}$ of the antiserum inhibited half the cataly tic activity of $1 \mu \mathrm{g}$ of pure enzyme protein $(0.1 \mathrm{U})$.

\section{Statistical evaluation}

Mean values were expressed as the mean \pm SD. Student's $t$ test was used for statistical evaluation.

\section{Results}

\section{Urinary angiotensin converting enzyme activity}

Urinary angiotensin converting enzyme activities in normal subjects $(n=18)$ and patients with nephrotic syndrome $(n=15)$ and chronic glomerulonephritis $(n=12)$ were $0.38 \pm 0.10,1.58 \pm 0.50$ and $1.01 \pm 0.45$ units/day $(\bar{x} \pm s)$, respectively (fig. 1). Urinary angiotensin converting enzyme activities were significantly higher in patients with nephrotic syndrome $(p<0.001)$ and chronic glomerulonephritis $(p<0.005)$ than that of normal subjects. There was no relationship between the enzymic activity and the concentration of sodium excretion in patients with nephrotic syndrome $(r=0.13$, $\mathrm{p}>0.2)$ and chronic glomerulonephritis $(\mathrm{r}=-0.38$, $0.2>p>0.1$ ). Furthermore, there was no significant correlation between angiotensin converting enzyme activity and protein amount excreted in the urine $(\mathrm{r}=0.36, \mathrm{p}>0.1)$.

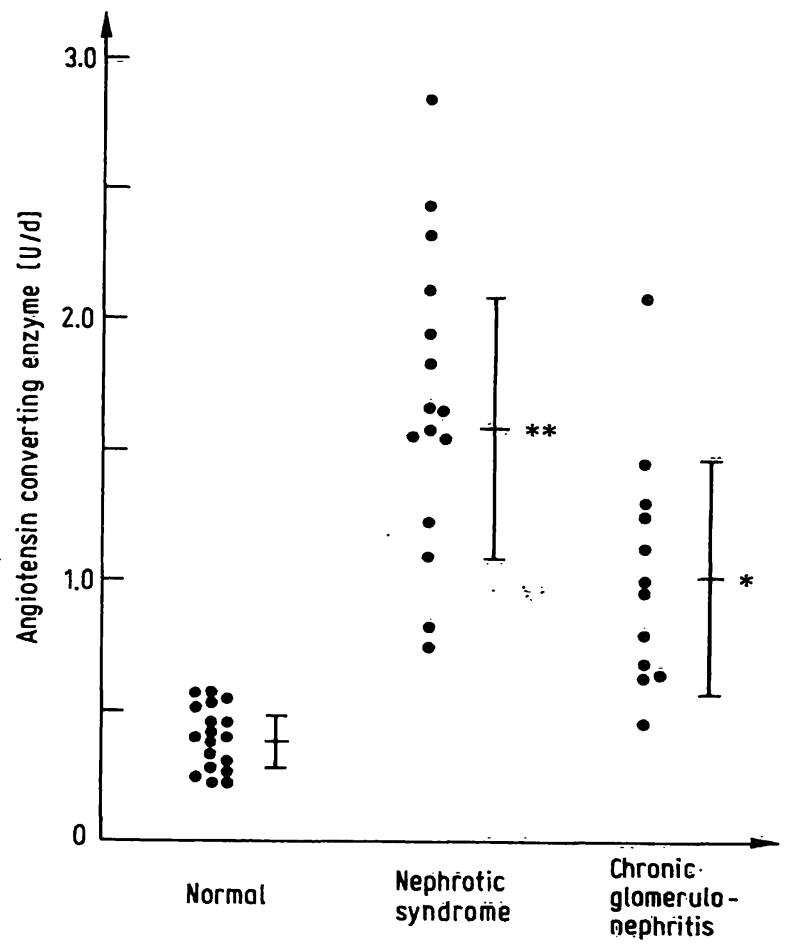

Fig. 1. Angiotensin converting enzyme activities in urine samples from normal subjects $(n=18)$ and patients with nephrotic syndrome $(n=15)$ and chronic glomerulonephritis $(n=12) .200 \mu l$ of the urine samples fractionated with $3.14 \mathrm{~mol} / 1$ ammonium sulfate was assayed with $2 \mathrm{mmol} / \mathrm{l}$. hippuryl-His-Leu as substrate. The enzymic activity was expressed as units/day. Bars indicate the mean \pm SD: $* \mathrm{p}<0.005 ; * * \mathrm{p}<0.001$

\section{Multiple forms of angiotensin converting enzyme in human urine}

Fresh urine samples $(150 \mathrm{ml})$ from 5 normal subjects and 4 nephrotic patients were dialysed against $10 \mathrm{mmol} / \mathrm{l}$ phosphate buffer, pH 7.8 at $4^{\circ} \mathrm{C}$ overnight. Each sample (3-4 ml) concentrated with Amicon PM 10 
membrane was applied to a column of Sephadex G-200 $(2.6 \times 90 \mathrm{~cm})$. Fractions of $3.25 \mathrm{ml}$ were collected. Typical profiles from normal subjects and patients with nephrotic syndrome are shown in figure 2 .

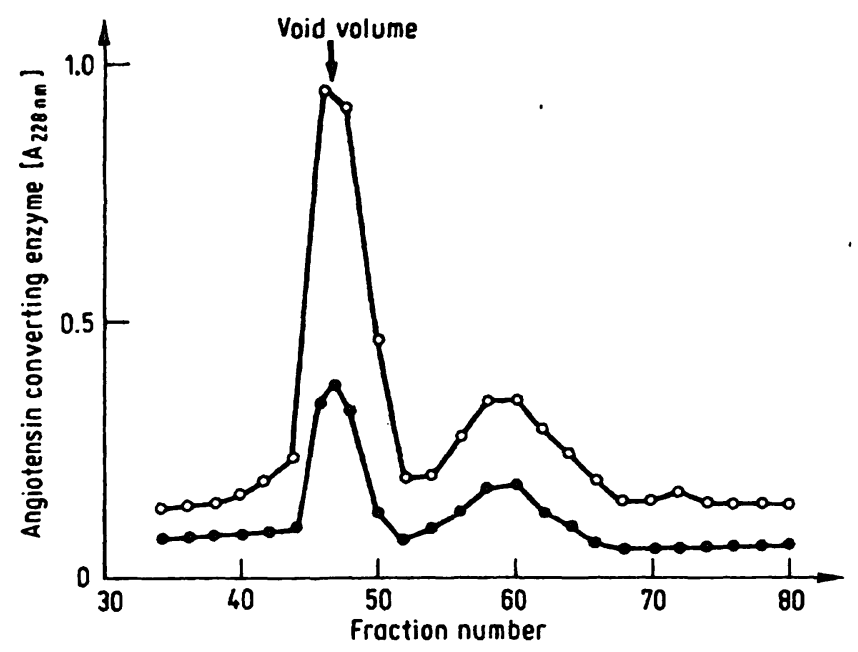

Fig. 2. Sephadex G-200 column chromatography of human urine. Applied samples; concentrated urine samples with Amicon PM 10 filter. The arrow indicates the void volume determined with Blue Dextran 2000. Fraction volume $3.25 \mathrm{ml}$.

- Enzymic activity in the urine from one normal subject.

- - Enzymic activity in the urine from one nephrotic patient.

The enzymic activities appeared in fractions of

No. 42-48 (high molecular weight) and No. 52-63

(low molecular weight). The ratios of the enzymic activity of high molecular weight form $\left(M_{\mathrm{r}}>400000\right)$

against that of low molecular weight form $\left(M_{\mathrm{r}}=290000\right)$ in 5 normal subjects and 4 nephrotic patients were $1.5 \pm 0.45$ and $3.8 \pm 1.4$, respectively.

After trypsin treatment ( $1 \mathrm{mg}$ trypsin/10 $\mathrm{mg}$ of protein in the enzyme material) for $2 \mathrm{~h}$ at $37^{\circ} \mathrm{C}$, only the low molecular weight form appeared in gel filtration on Sephadex G-200 (Fig. 3).

\section{Properties of low molecular weight and high molecular weight forms of urinary angiotensin converting enzyme}

Low molecular weight and high molecular weight forms of urinary angiotensin converting enzyme from normal subjects were partially purified by DEAE-cellulose column chromatography and Sephadex G-200 gel filtration and used as a sample for the following experiments.

$\mathrm{pH}$ optimum: The $\mathrm{pH}$ dependence of hydrolysis of hippuryl-His-Leu in $80 \mathrm{mmol} / \mathrm{l}$ borate-sodium carbonate buffer, between pH 6 and 9 with low molecular weight and high molecular weight forms of urinary angiotensin converting enzyme, showed a maximum around $\mathrm{pH} 8.3$, which corresponded with that of the pure human kidney angiotensin converting enzyme (10).
$K_{\mathrm{m}}$ value: $K_{\mathrm{m}}$ values of low molecular weight and high molecular weight forms of angiotensin converting enzyme were determined from the Lineweaver-Burk plot at 7 different substrate concentrations in $80 \mathrm{mmol} / \mathrm{l}$ borate-sodium carbonate buffer, $\mathrm{pH}$ 8.3. $K_{\mathrm{m}}$ values of low molecular weight and high molecular weight forms of angiotensin converting enzyme were $2.0 \mathrm{mmol} / 1$ and identical with that of angiotensin converting enzyme purified from human kidney.

Chloride ion dependency: The reactions of low molecular weight and high molecular weight forms of angiotensin converting enzyme were carried out in the presence of various concentrations of $\mathrm{NaCl}(0.1-$ $1.2 \mathrm{~mol} / \mathrm{l})$. The highest activity in both forms of angiotensin converting enzyme was observed at the concentration of $0.8 \mathrm{~mol} / 1 \mathrm{NaCl}$. The purified human kidney angiotensin converting enzyme showed the same result.

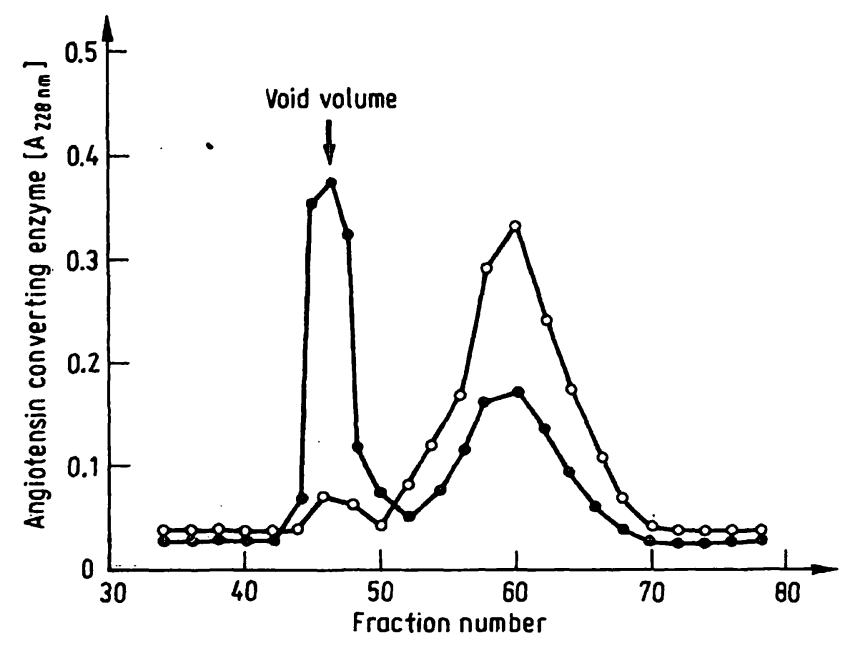

Fig. 3. Sephadex G-200 column chromatography of human urine sample with or without trypsin treatment. Applied samples: trypsin-treated sample and non-treated sample. The arrow indicates the void volume determined with Blue Dextran 2000. Fraction volume $3.25 \mathrm{ml}$. - - Enzymic activity in non-treated urine sample. - - E Enzymic activity in trypsin-treated urine sample.

Effects of captopril and rabbit antiserum to human kidney angiotensin converting enzyme: Both enzymic activities of low molecular weight and high molecular weight forms were inhibited completely by $1 \mu \mathrm{mol} / 1$ captopril. $I_{50}$ of captopril was identical for low and high molecular weight forms of urinary angiotensin converting enzyme ( $21 \mathrm{nmol} / \mathrm{l})$. Low molecular weight and high molecular weight forms of urinary angiotensin converting enzyme were incubated with varying amounts of anti-human kidney angiotensin converting enzyme antiserum in $80 \mathrm{mmol} / \mathrm{l}$ borate-sodium carbonate buffer, $\mathrm{pH} 7.8$ at $37^{\circ} \mathrm{C}$ for $30 \mathrm{~min}$ and the remaining enzymic activities of both forms of angiotensin converting enzyme (each 0.1 unit) were inhibited similarly. Five $\mu \mathrm{l}$ of the antiserum inhibited about $50 \%$ of the activities of low and high molecular weight forms of urinary angiotensin converting enzyme. 


\section{Discussion}

Recently Baggio et al. (11) reported that urinary angiotensin converting enzyme was significantly increased in patients affected by upper urinary tract infection and nephrolithiasis. Partially purified urinary angiotensin converting enzyme showed the highest activity at a $\mathrm{NaCl}$ concentration of $0.8 \mathrm{~mol} / 1$, but we measured the activity in urine samples in $0.3 \mathrm{~mol} / 1 \mathrm{NaCl}$ to avoid the interference of turbidity sometimes seen at $0.8 \mathrm{~mol} / 1$ $\mathrm{NaCl}$. We demonstrated that angiotensin converting enzyme activity in urine was significantly higher in patients with nephrotic syndrome and chronic glomerulonephritis than in normal subjects. However, there was no significant relationship between urinary angiotensin converting enzyme activity and the amount of protein excreted in the urine. In nephrotic patients, an increase in urinary angiotensin converting enzyme activity was due mainly to an increased release of the high molecular weight form of angiotensin converting enzyme. This high molecular weight form of angiotensin converting enzyme cannot be detected in serum (12). The high molecular weight form of urinary angiotensin converting enzyme changed to the low molecular form when treated with trypsin. The molecular weight of the low molecular weight form of the enzyme was the same as those of human serum angiotensin converting enzyme (12) and angiotensin converting enzymes from human kidney (10) and human lung (13), both of which were solubilized from membrane fractions with trypsin. Properties of both low and high molecular weight forms of urinary angiotensin converting enzyme were identical with those of the enzyme purified from human kidney with respect to $\mathrm{pH}$ optimum, $K_{\mathrm{m}}$ value, chloride ion dependency and inhibition by captopril or antiserum to human kidney angiotensin converting enzyme.

Various enzymes are present in urine as a result of their direct release from the kidney into the urine (14). In patients with chronic glomerulonephritis with or without nephrotic syndrome, membrane-bound enzymes specific for the luminal portion of proximal epithelia were excreted in the urine at an increased rate (15).

\section{References}

1. Skeggs, L. T., Kahn, J. R. \& Shumway, N. P. (1956) J. Exp. Med. 103, 295-299.

2. Soffer, R. L. (1976) Ann. Rev. Biochem. 45, 73-94.

3. Nishimura, K., Yoshida, N., Hiwada, K., Ueda, E. \& Kokubu, T. (1977) Biochim. Biophys. Acta 483, 398-408.

4. Ward, P. E., Gedney, C. D., Dowben, R. M. \& Erdös, E. G. (1975) Biochem. J. 151, 755-758.

5. Caldwell, P. R. B., Seegal, B. C., Hsu, K. C., Das, M. \& Soffer, R. L. (1976) Science 191, 1050-1051.

6. Kokubu, T., Kato, I., Nishimura, K., Hiwada, K. \& Ueda, E. (1978) Clin. Chim. Acta 89, 375-379.

7. Cushman, D. W. \& Cheung, H. S. (1971) Biochem. Pharmacol. 20, 1637-1648.

8. Hiwada, K., Ito, T., Yokoyama, M. \& Kokubu, T. (1980) Eur. J. Biochem. 104, 155-165.

9. Lowry, O. H., Rosebrough, N. J., Farr, A. L. \& Randall, R. J. (1951) J. Biol. Chem. 193, 265-275.
Hiwada et al. (16) have reported that aminopeptidase $\mathbf{N}$ (EC 3.4.11.2) in urines from nephrotic children is significantly higher than that from normal children. The high molecular weight form of aminopeptidase $\mathrm{N}$ was identical with the enzyme originating from the brush border of tubular cells. The ratio of high molecular weight form to low molecular weight form of urinary aminopeptidase $\mathrm{N}$ was almost unchanged in urines from normal and nephrotic children. On the other hand, the ratio of high molecular weight to low molecular weight forms of urinary angiotensin converting enzyme was increased in nephrotic patients compared with normal subjects. It is suggested that urinary angiotensin converting enzyme is released from the kidney into urine as a high molecular wëight form and this high molecular weight form is altered in part to the low molecular weight form by trypsin-like enzyme(s) in urine. Both angiotensin converting enzyme and aminopeptidase $\mathrm{N}$ are membrane-bound enzymes. The mechanism of release of angiotensin converting enzyme and aminopeptidase $\mathbf{N}$ from the brush border of tubular cells seems to be different.

We found a significant correlation between sodium and angiotensin converting enzyme excretion in normal subjects (6). In nephrotic syndrome and chronic glomerulonephritis, however, such a relationship between sodium and angiotensin converting enzyme excretion was not observed, and the high molecular weight form of angiotensin converting enzyme was increased more than the low molecular weight form. This means that increased urinary angiotensin converting enzyme excretion under pathologic conditions mainly depends on the damage of proximal tubular cells as suggested by Scherberich \& Mondorf (15), resulting in the loss of correlation between sodium and angiotensin converting enzyme excretion observed in normal subjects.

\section{Acknowledgement}

This work was supported in part by a Grant-in-Aid for Encouragement of Young Scientist (No. 477327) from the Ministry of Education, Science and Culture of Japan.

10. Takada, Y., Hiwada, K. \& Kokubư,-T. (1981) J. Biochẹm. (Tokyo) 90, 1309-1319.

11. Baggio, B., Favaro, S., Cantaro; S., Bertazzo, L., Frunzio, A. \& Borsatti, A. (1981) Clin. Chim. Acta 109, 211-218.

12. Ueda, E., Nishimura, K., Kato, I., Hayashi, Y., Kokubu, T., Yoshida, N. \& Tachibana, T. (1978) Jap. J. Thorac. Dis. 16, 94-97.

13. Nishimura, K., Yoshida, N., Hiwada, K., Ueda, E. \& Kokubu, T. (1978) Biochim. Biophys. Acta 522, 229-237.'

14. Raab, W. P. (1972) Clin. Chem. 18, 5-25.

15. Scherberich, J. E. \& Mondorf, W. A. (1979) Excretion of kidney brush border antigens as a quantitative indicator of tubular damage: In: Diagnostic Significance of Enzymes and Proteins in Urine (Dubach, U. C. \& Schmidt, U. eds.), Hans Hubex Publishes, Bern, Stuttgart and Vienna.

16. Hiwada, K., Yaminguchi, C., Iñaoka, Y.\& Kokúbụ, T. (1976) Clin. Chim. Acta 75, 31-39. : 